\title{
Phytochemical-rich medicinal plant extracts suppress bacterial antigens-induced inflammation in human tonsil epithelial cells
}

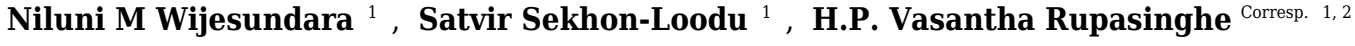 \\ 1 Department of Plant, Food, and Environmental Sciences, Faculty of Agriculture, Dalhousie University, Truro, NS, Canada \\ Department of Pathology, Faculty of Medicine, Dalhousie University, Halifax, NS, Canada \\ Corresponding Author: H.P. Vasantha Rupasinghe \\ Email address: vrupasinghe@dal.ca
}

Background:

Pharyngitis is an inflammatory condition of the pharynx and associated structures commonly caused by the Group A streptococci (GAS). There is a growing interest in discovering plant-based anti-inflammatory compounds as potential alternatives to conventional drugs. This study evaluated anti-inflammatory activity of phytochemical-rich extracts prepared from 12 herbal plants using human tonsil epithelial cells (HTonEpiC) in vitro.

Methods: The HTonEpiC were induced by a mixture of lipoteichoic acid (LTA) and peptidoglycan (PGN) (10 $\mu \mathrm{g} / \mathrm{mL}$; bacterial antigens) for $4 \mathrm{~h}$ and then exposed to ethanol extracts (EE) or aqueous extracts (AE) for $20 \mathrm{~h}$. The secretion of four pro-inflammatory cytokines was measured using enzyme-linked immunosorbent assays (ELISA). Total phenolic and total flavonoid contents of the extracts were determined using spectrophotometric methods.

Results: The herbal plant extracts ( $\leq 5 \mu \mathrm{g} / \mathrm{mL}$ ) were not cytotoxic to HTonEpiC. The extracts exhibited a broad range of reduction ( $1.2 \%$ to $92.6 \%$ ) of secretion of interleukin-8 (IL-8), human beta defensin-2 (hBD-2), epithelial-derived neutrophil activating protein-78 (ENA-78), and granulocyte chemotactic protein-2 (GCP-2). Both EE and AE of clove, ginger, and echinacea flower and EE from danshen root significantly inhibited the pro-inflammatory cytokine production as induced by LTA and PGN in HTonEpiCs at a concentration of 1 and $5 \mu \mathrm{g} / \mathrm{mL}$.

Discussion: Our observations indicate that danshen root, clove, ginger, and echinacea flower extracts exhibit an anti-inflammatory effect in HTonEpiCs. The most efficacious extracts from danshen root, clove, ginger and echinacea flowers have potential to be used as natural sources for developing phytotherapeutic products in the management of painful inflammation due to streptococcal pharyngitis. 
1 Phytochemical-rich medicinal plant extracts suppress bacterial antigens-induced

2 inflammation in human tonsil epithelial cells

3

4

5 Niluni M. Wijesundara ${ }^{a}$, Satvir Sekhon-Loodu ${ }^{a}$, H. P. Vasantha Rupasinghe a,b *

6

7 aDepartment of Plant, Food, and Environmental Sciences, Faculty of Agriculture, Dalhousie

8 University, Truro, NS, Canada;

9 bepartment of Pathology, Faculty of Medicine, Dalhousie University, Halifax, NS, Canada.

10

11

12 Short title: Anti-inflammatory plant extracts

13

14

15

16

17

18

19

20

21

22 *To whom correspondence should be addressed: Tel: +1 902893 6623. Fax: +1 9028931404.

23 E-mail: vrupasinghe@dal.ca. 


\section{ABSTRACT}

25

26

27

\section{Background}

Pharyngitis is an inflammatory condition of the pharynx and associated structures commonly caused by the Group A streptococci (GAS). There is a growing interest in discovering plant-based anti-inflammatory compounds as potential alternatives to conventional drugs. This study evaluated anti-inflammatory activity of phytochemical-rich extracts prepared from 12 herbal plants using human tonsil epithelial cells (HTonEpiC) in vitro.

\section{Methods}

The HTonEpiC were induced by a mixture of lipoteichoic acid (LTA) and peptidoglycan (PGN) (10 $\mu \mathrm{g} / \mathrm{mL}$; bacterial antigens) for $4 \mathrm{~h}$ and then exposed to ethanol extracts (EE) or aqueous extracts (AE) for $20 \mathrm{~h}$. The secretion of four pro-inflammatory cytokines was measured using enzyme-linked immunosorbent assays (ELISA). Total phenolic and total flavonoid contents of the extracts were determined using spectrophotometric methods.

\section{Results}

The herbal plant extracts $(\leq 5 \mu \mathrm{g} / \mathrm{mL})$ were not cytotoxic to HTonEpiC. The extracts exhibited a broad range of reduction $(1.2 \%$ to $92.6 \%)$ of secretion of interleukin-8 (IL-8), human beta defensin-2 (hBD-2), epithelial-derived neutrophil activating protein-78 (ENA-78), and granulocyte chemotactic protein-2 (GCP-2). Both EE and AE of clove, ginger, and echinacea flower and EE from danshen root significantly inhibited the pro-inflammatory cytokine production as induced by LTA and PGN in HTonEpiCs at a concentration of 1 and $5 \mu \mathrm{g} / \mathrm{mL}$.

\section{Discussion}

Our observations indicate that danshen root, clove, ginger, and echinacea flower extracts exhibit an anti-inflammatory effect in HTonEpiCs. The most efficacious extracts from danshen root, 
47 clove, ginger and echinacea flowers have potential to be used as natural sources for developing 48 phytotherapeutic products in the management of painful inflammation due to streptococcal 49 pharyngitis. 


\section{Introduction}

The prevalence of streptococcal pharyngitis has increased worldwide during the last decades. Streptococcus pyogenes, a group A streptococcus (GAS), is the main bacterial etiology responsible for $15 \%$ to $36 \%$ of acute pharyngitis in children (Abachi et al. 2016). The inflammatory response of epithelial cells of the upper respiratory tract act as the first line of defense recruited to combat GAS (Rock et al. 2010). Toll-like receptors (TLR) in host cells are involved in the recognition of cell wall compounds of $S$. pyogenes, especially lipoteichoic acid (LTA) and peptidoglycan (PGN), which are responsible for host-pathogen interactions (Bisno et al. 2003). Bacterial virulence factors induce tonsil epithelial cells and white blood cells to produce chemical mediators of inflammation such as cytokines, chemokines, and prostaglandins (Ricciotti \& FitzGerald 2011).

Non-steroidal anti-inflammatory drugs (NSAID), such as aspirin, ibuprofen, nimesulide, piroxicam, and ketoprofen are widely recommended by physicians for the management of inflammatory conditions (Cremonesi \& Cavalieri 2015). NSAID inhibit the cyclooxygenase-2 (COX-2), which is responsible for the synthesis of pro-inflammatory prostaglandins (Ricciotti \& FitzGerald 2011). Some patients are allergic to NSAID and may develop shortness of breath after intake (Kim et al. 2013). Physicians reluctant to give steroids to children due to possible long-term side effects (Schams \& Goldman 2012).

Pharmaceutical and natural health product industries have been interested in identifying specific medicinal plants as sources of unique phytochemicals with pharmacological properties. Oregano L., Salvia L. and Thymus L., three important genera of the Lamiaceae family, are spice herbs that are traditionally used for flavoring food in North America (Fournomiti et al. 2015). Spices such as ginger and clove are also used globally in food flavoring, confectioneries, 
73 beverages, and cosmeceuticals (Chaieb et al. 2007; Park et al. 2008). Native Americans and early

74 settlers used Echinacea, geranium, slippery elm, barberry and licorice as medicinal herbs.

75 Traditionally, the tea made from the leaves of Echinacea and geranium or roots of barberry and

76 licorice have been largely used in North America as a soothing agent for infections and

77 inflammations (Borchers et al. 2000).

78 Thus, the aim of this study was to investigate the anti-inflammatory properties of aqueous

79 and ethanol extracts prepared from 12 herbs, which were selected based on the reported literature

80 and geographical availability and traditional practice in Canada. Cell viability, production of pro-

81 inflammatory biomarkers, and cell morphological changes were determined using human tonsil

82 epithelial cell (HTonEpiC) model to identify efficacious extracts, with the future aim of developing

83 an herbal extract incorporated natural health product in the management of streptococcal

84 pharyngitis associated inflammation.

\section{2. Materials and methods}

\section{2.1. Plant materials}

87 Twelve different herbal plants that were used in Canadian traditional medicine were selected for 88 the study. Purple coneflower/Echinacea areal parts (Voucher No: 13009), geranium leaves 89 (Voucher No: 13010), sage leaves (Voucher No: 13011), oregano flowering shoots (Voucher No:

90 13012), and thyme flowering shoots (Voucher No: 13013), were collected during the flowering 91 period from the herb garden at the Faculty of Agriculture, Dalhousie University (GPS location $\left.924^{\circ} 22^{\prime} 23.3^{\prime \prime N} 63^{\circ} 15^{\prime} 45.2^{\prime \prime} \mathrm{W}\right)$. A taxonomist, Jeff Morton, Faculty of Agriculture, Dalhousie 93 University, Canada, authenticated plants. The specimens were deposited in the A.E. Roland 94 herbarium, Department of Plant, Food, and Environmental Sciences, Faculty of Agriculture, 95 Dalhousie University, Canada. Fresh ginger rhizome, and dried clove flower buds were purchased 
96 from Halifax (NS, Canada). A dry powder of barberry root, licorice root, slippery elm/red elm

97 inner bark and olive leaves were purchased from Mother Earth Natural Health, Ottawa, ON,

98 Canada. Danshen roots were obtained from Green Man Botanicals (Gaspereau Mountain, NS,

99 Canada). Samples were dried at $50{ }^{\circ} \mathrm{C}$ for 3 days, ground, and stored at $-80{ }^{\circ} \mathrm{C}$.

100

101

102

103

104

105

106

107

108

109

110

111

112

113

114

115

116

117

\subsection{Preparation of extracts of medicinal plants}

\subsubsection{Aqueous extracts (AE)}

The AEs were prepared using a previously described method (Gunathilake \& Rupasinghe 2014). Plant powder and distilled water (1:10) was boiled using a ISOTEMPTM water bath (Model 205, Fisher Scientific, Ottawa, ON, Canada) for $10 \mathrm{~min}$ and were filtered. Collected filtrates were freeze overnight and were dried in a freeze dryer (Kinetics, FTS Systems Inc., Stone Ridge, NY, USA) under $3600 \mathrm{mT}$ vacuum and $-20^{\circ} \mathrm{C}$ for $48 \mathrm{~h}$ and were stored in airtight amber glass bottles at -80 ${ }^{\circ} \mathrm{C}$.

\subsubsection{Ultrasonic-assisted ethanol extracts (EE)}

The mixture of plant powder and 95\% ethanol (1:10) kept in a sonication bath $(750 \mathrm{D}, \mathrm{VWR}$, West Chester, PA, USA $)$ at $35^{\circ} \mathrm{C}$ for 45 min $(3 \times 15$ min with 5 min of intervals $)$ at $40 \mathrm{kHz}$ frequency and $150 \mathrm{~W}$ ultrasonic power. The residues were removed by filtering through a vacuum pump and were evaporated to dryness using a rotary evaporator (R-200, Buchi, Flawil, Switzerland) at $45^{\circ} \mathrm{C}$ for 20 to $30 \mathrm{~min}$. Remained solids were dissolved in anhydrous ethanol and kept under the nitrogen evaporator (N-EVAP ${ }^{\mathrm{TM}}$, Organomation Association Inc., Berlin, NJ, USA). After completely dry, the extracts were preserved in airtight amber glass bottles at $-80^{\circ} \mathrm{C}$.

\subsection{Phytochemical analysis}

\subsubsection{Determination of total phenolic (TP) content}


118 The Folin Ciocalteu assay was performed to estimate the TP content using a previously described

119 method (Rupasinghe et al. 2010). The TP was calculated using a standard curve prepared with

120 gallic acid and were expressed as milligrams of gallic acid equivalents (GAE) per gram of dry

121 solid of extract.

\section{2.3.2. Determination of total carotenoids (TC) content}

123 The TC assay was performed using a previously described method (Rivera \& Canela 2012). The

$124 \mathrm{TC}$ values were calculated using the equation; $\mathrm{TC}=(\mathrm{A} \times 10000 \times \mathrm{V}) /(\mathrm{A}(1 \% / 1 \mathrm{~cm}) \times \mathrm{W} \times \mathrm{L})$,

125 where $A$ is the absorbance at $470 \mathrm{~nm}, \mathrm{~V}$ is the total volume of extract, $\mathrm{A}(1 \% / 1 \mathrm{~cm})$ is the extinction

126 coefficient for a mixture of solvents arbitrarily set at $2500, \mathrm{~W}$ is the sample weight in grams and

$127 \mathrm{~L}$ is the path length for the sample volume in the plate. TC content was expressed as $\mu \mathrm{g} / \mathrm{mL}$ of dry

128 solid of extract.

$129 \quad$ 2.4. Cell culture

130 The HTonEpiC cells (ScienCell Research Laboratory, San Diego, CA, USA) were cultured and 131 maintained according to the manufacturer's guidelines. Briefly, HTonEpiC were cultured in poly132 L-lysine (PLL) (Sigma-Aldrich Canada Ltd, Oakville, ON, Canada) coated flask (2 $\mu \mathrm{g} / \mathrm{cm}^{2} \mathrm{~T}-75$ 133 flask) with complete growth medium (CGM) and maintained at $37{ }^{\circ} \mathrm{C}$ in a $5 \% \mathrm{CO}_{2}$ humidified 134 atmosphere in an incubator (Model 3074, VWR International, West Chester, PA, USA). CGM was 135 prepared by mixing growth supplement and penicillin/streptomycin solution with tonsil epithelial 136 cell medium at 1:1:100 ratio.

\section{2.5. Cell viability assay}

138 Cell viability was determined using the 3-(4,5-dimethylthiazol-2-yl)-5-(3139 carboxymethoxyphenyl)-2-(4-sulfophenyl)-2H-tetrazolium (MTS) (Sigma-Aldrich Canada Ltd, 140 Oakville, ON, Canada) assay. Briefly, cells were cultured at a density of 6,000 cells/100 $\mu \mathrm{L}$ in 96- 
141 well plates pre-coated with PLL and treated with EE and AE at concentrations of $0.5-100 \mu \mathrm{g} / \mathrm{mL}$,

142 solvent control (0.05\% DMSO) and Dulbecco's phosphate buffered saline buffer. A combination

143 of lipoteichoic acid (LTA) (Sigma-Aldrich Canada Ltd, Oakville, ON, Canada) and peptidoglycan

144 (PGN) (Cedarlane Laboratories, Burlington, ON, Canada) (10 $\mu \mathrm{g} / \mathrm{mL})$ was used as a bacterial

145 antigen control and nimesulide $(0.5,1$, and $5 \mu \mathrm{g} / \mathrm{mL})$ was tested as a positive control. After $24 \mathrm{~h}$

146 incubation under $5 \% \mathrm{CO}_{2}$ at $37^{\circ} \mathrm{C}$, the cells were refreshed by adding $100 \mu \mathrm{L}$ of fresh CGM. Then

147 cells were incubated with $20 \mu \mathrm{L}$ of MTS reagent [MTS + phenazine methosulfate (PMS)] for 2.5

$148 \mathrm{~h}$. The absorbance was measured at $490 \mathrm{~nm}$ and cell viability was calculated using the following 149 equation.

150 Cell Viability $(\%)=\frac{\text { Absorbance of the treated wells-Absorbance of the blank }}{\text { Absorbance of the control wells-Absorbance of the blank }} \times 100$, where the 151 treated wells contained cells incubated with test compounds, the control wells contained cells with 152 solvent and CGM, and the blank wells contained CGM only.

\section{2.6. Treatment of plant extracts}

154 The HTonEpiC were seeded at a density of $35 \times 10^{3}$ cells/well in PLL coated 24-well plates and 155 incubated overnight at $35^{\circ} \mathrm{C}$ for $20 \mathrm{~h}$. The cells were stimulated with a mixture of LTA and PGN 156 (each at $10 \mu \mathrm{g} / \mathrm{mL}$ ) for $4 \mathrm{~h}$ incubation at $35^{\circ} \mathrm{C}$ to trigger inflammation. Then, the cells were treated 157 with either $\mathrm{EE}$ or $\mathrm{AE}$ at 1 and $5 \mu \mathrm{g} / \mathrm{mL}$ concentrations and incubated at $35{ }^{\circ} \mathrm{C}$ for $24 \mathrm{~h}$. The cells 158 were stimulated with LTA and PGN for $4 \mathrm{~h}$ and $24 \mathrm{~h}$. Nimesulide as the reference control and $1590.05 \%$ of DMSO as the experimental control were used. The supernatants were collected for 160 determination of pro-inflammatory biomarkers.

\subsection{Determination of pro-inflammatory cytokines and chemokines}

162 The concentrations of pro-inflammatory cytokines were measured from the culture medium of 163 control and treated cells by using ELISA kits according to the manufacturer's instructions. 
164

165

166

167

168

169

170

171

172

173

174

175

176

177

178

179

180

181

182

183

184

185

186

\subsubsection{Interleukin-8 (IL-8) assay}

The concentration of IL-8 was measured by using the IL-8 ELISA kit (BD Biosciences, Mississauga, ON, Canada). Anti-human monoclonal antibodies coated plates were developed by using detection antibodies and streptavidin-horseradish peroxidase (HRP) conjugate provided with the kit, according to the instructions. First, $50 \mu \mathrm{L}$ diluent was added to each well of anti-human IL-8 monoclonal antibody coated 96-well plates, and then standards and samples $(100 \mu \mathrm{L})$ were pipetted into appropriate wells. Plates were incubated for $2 \mathrm{~h}$ at room temperature with gentle shaking. Subsequently, well-washing step, $100 \mu \mathrm{L}$ of detecting antibody was added. The covered plates were incubated for $1 \mathrm{~h}$ at room temperature, followed by seven rinsing steps. Then, 100 $\mu \mathrm{L} /$ well of 3, 3', 5, 5'-tetramethylbenzidine (TMB) substrate was added and were incubated for $30 \mathrm{~min}$ at room temperature in the dark. Then, the stop solution (0.16 M sulfuric acid) was added (50 $\mu \mathrm{L} /$ well) and absorbance was read at $450 \mathrm{~nm}$. The concentration of IL-8 was expressed as $\mathrm{pg} / \mathrm{mL}$ using the standard curve and presented as the percentage of the inflammation control.

\subsubsection{Human Beta Defensin-2 (hBD-2) assay}

The content of hBD-2 was determined by an hBD-2 ELISA kit (PromoCell GmbH, Sickingenstrabe, Heidelberg, Germany). Anti-hBD-2 antibody coated plates were prepared using detection antibody and avidin-HRP conjugate, according to the manufacturer's protocol. The 96well plates were coated with capture antibody and incubated overnight at room temperature. Samples/standards $(100 \mu \mathrm{L})$ were added in triplicates to appropriate wells after rinsing. Followed by a $2 \mathrm{~h}$ incubation at room temperature, plates were washed four times with washing buffer. Then, the plates were incubated for another $2 \mathrm{~h}$ at room temperature along with detection antibody. The avidin-HRP conjugate was pipetted and incubated for $30 \mathrm{~min}$. 2, 2'-Azino-bis (3ethylbenzothiazoline-6-sulfonic acid) liquid substrate was added for color development and were 
187 read at the absorbance of $405 \mathrm{~nm}$.

188 2.7.3. Epithelial-derived Neutrophil Activating protein-78 (ENA-78) assay

189 The human ENA-78 ELISA kit (Ray Biotech, Inc., Norcross, GA, USA) was used to detect the \% 190 secretion of the ENA-78 protein in the cell culture supernatant. Pre-coated 96-well plates with 191 specific antibody for human ENA-78 were used and the assay was performed according to the 192 manufacturer's instructions. Briefly, $100 \mu \mathrm{L}$ standards and samples were added to appropriate 193 wells and the plates were incubated overnight at $4{ }^{\circ} \mathrm{C}$ with gentle shaking. The solution was then 194 discarded and the plates were washed four times with wash solution. Then, $100 \mu \mathrm{L}$ of biotinylated 195 antibody was added to each well and incubated for $1 \mathrm{~h}$ at room temperature with gentle shaking. After four washing steps, $100 \mu \mathrm{L}$ of HRP-streptavidin solution was added to each well. After an 197 incubation period of $45 \mathrm{~min}$ at room temperature with gentle shaking, the plates were rinsed with wash buffer, followed by $100 \mu \mathrm{L}$ of TMB substrate reagent was added to each well and incubated for $30 \mathrm{~min}$ at room temperature with gentle shaking, protected from light. The reaction was ended by adding $50 \mu \mathrm{L}$ of stop solution $(0.16 \mathrm{M}$ sulfuric acid). Then, plates were read at the absorbance of $450 \mathrm{~nm}$. The ENA-78 concentration was calculated using a standard curve and the data is expressed as $\mathrm{pg} / \mathrm{mL}$.

\subsubsection{Granulocyte Chemotactic Protein-2 (GCP-2) assay}

The human GCP-2 ELISA kit (Ray Biotech, Inc., Norcross, GA, USA) was used to measure the protein production of GCP-2. GCP-2 microplate coated with anti-human GCP-2 was used. The ELISA procedure was similar to the description in the ENA-78 assay.

\subsection{Cell morphological assessment}

After the treatment with 1 and $5 \mu \mathrm{g} / \mathrm{mL}$ of extracts, the cells were examined under an inverted microscope (ECLIPSE TS 100/TS 100-F, Nikon Instruments Inc., Melville, NY, USA) with $40 \times$ 
210 magnification. The images were captured and saved using a Lumenara infinity camera (1-2 USB,

2112.9 Megapixel), coupled with capture and analyzing software (Infinity Analyze, Lumenara

212 Corporation, Ottawa, ON, Canada).

213 2.9. Statistical analysis

214 All the experiments were designed using completely randomized design. Cell viability

215 experiments were conducted in triplicate and independently three times whereas all the ELISA

216 experiments were run in triplicate and independently twice. Results were expressed as a

217 mean \pm standard error of the mean. One-way ANOVA analysis was performed by using Minitab

21817.0 statistical software and statistical differences $(\mathrm{P}<0.05)$ between means of pairs were resolved

219 by using Tukey's tests.

220 3. Results

221 3.1. Extraction yield and phytochemical analysis of herbal extracts

222 Phytochemical analysis of selected herbal plant parts used in this study have been reported 223 excessively in past. Table 1 summarizes the scientific names, major phytochemicals and their 224 therapeutic uses of the plants used in the present study. The extraction yields of AE, EE, TP, and 225 TC contents are shown in Table 2. Other than, in licorice EE, the extraction yields of AEs were 226 higher than their respective EEs. However, no exact relationship was observed between the plant 227 parts have been used in the extraction and the extraction yield. Both EE and AE of clove displayed 228 the highest TP content, followed by AE and EE of oregano, slippery elm, thyme, geranium, and 229 ginger. The EE from leaves were showed higher TC content than EEs derived from roots, flowers 230 or stem. Therefore, thyme, oregano, sage, echinacea leaves and geranium exhibited significant 231 high TC. Furthermore, EEs showed higher TC content than their respective AEs. 


\section{3.2. Cytotoxic effect of selected phytochemicals-rich extracts on human tonsil epithelial cells.}

233 The suppressive effect of extract is expected only to happen on pro-inflammatory cytokines

234 production in inflamed cells. If normal throat epithelium cells are affected by treated extracts, they

235 may not use as anti-inflammatory agents in natural health product or in drugs. Therefore,

236 cytotoxicity of both EEs and AEs on HTonEpiC were evaluated by MTS assay. The HTonEpiC

237 were incubated $24 \mathrm{~h}$ with $14 \mathrm{EE}$ and $13 \mathrm{AE}$ at various concentrations ranged $0.5-100 \mu \mathrm{g} / \mathrm{mL}$. The

238 geranium leaves showed cytotoxic effects at $\geq 1 \mu \mathrm{g} / \mathrm{mL}$ for $\mathrm{EE}$ and at $>5 \mu \mathrm{g} / \mathrm{mL}$ for AE (Please

239 see supplementary data, Table S1). The EE of sage leaves were cytotoxic at higher concentrations

240 than $5 \mu \mathrm{g} / \mathrm{mL}$, where $\%$ cell viabilities were $33.1 \pm 1.7,29.5 \pm 0.8,24.4 \pm 0.9$ and $25.3 \pm 1.8$ for sage

241 EE and at the concentrations of 10, 25, 50, and $100 \mu \mathrm{g} / \mathrm{mL}$, respectively. Similarly, 25, 50, and

$242100 \mu \mathrm{g} / \mathrm{mL}$ concentrations of EE of licorice were also showed cytotoxicity to HTonEpiC. All other

243 extracts showed significantly higher cell viability $(>80 \%)$ without demonstrating cytotoxicity to

244 the HTonEpiC when the concentrations were between 0.5 to $5 \mu \mathrm{g} / \mathrm{mL}$ in $\mathrm{AE}$ and cell viability $\%$

245 were shown in Table 3 (Concentrations for 10, 25, 50, and $100 \mu \mathrm{g} / \mathrm{mL}$ were tested; Table S1 and

246 S2). Bacterial antigen mixture (PGN+LTA) had no significant cytotoxicity at the tested

247 concentration of $10 \mu \mathrm{g} / \mathrm{mL}(96.4 \pm 1.6 \%$ of cell viability for $\mathrm{AE}$ and $96.8 \pm 1.1 \%$ for $\mathrm{EE})$.

248 Nimesulide showed low cytotoxicity to the cells at all the concentrations tested. The concentrations

249 of 1 and $5 \mu \mathrm{g} / \mathrm{mL}$ of extracts were chosen to induce cells for inflammation study. 
250

251

252

253

254

255

256

257

258

259

260

261

262

263

264

265

266

267

268

269

270

271

272

\subsection{Effect of phytochemical-rich extracts on morphological changes of human tonsil} epithelial cells.

Further verification of morphological alterations was attained from phase contrast microscopy. We examined the HTonEpiCs that were treated with CGM, 0.05\% DMSO, $10 \mu \mathrm{g} / \mathrm{mL}$ LTA+PGN and plant extracts at the concentration of $5 \mu \mathrm{g} / \mathrm{mL}$ (Figures 1 and 2). The $5 \mu \mathrm{g} / \mathrm{mL}$ extracts showed significantly higher suppression of pro-inflammatory cytokines than $1 \mu \mathrm{g} / \mathrm{mL}$ extracts $(\mathrm{p} \leq 0.05)$. Therefore, only the results of \% total production of biomarkers of LTA and PGN-induced HTonEpiC at $5 \mu \mathrm{g} / \mathrm{mL}$ are reported. No changes in cell morphology and density were observed between untreated and DMSO-treated HTonEpiCs. Some morphological changes are shown after treatment of AEs (Figure 1) and EEs (Figure 2) at the concentrations of $5 \mu \mathrm{g} / \mathrm{mL}$ such as changes in size, shape, and reduction of cell density due to inflammation. Moreover, treatment with 10 $\mu \mathrm{g} / \mathrm{mL}$ LTA + PGN, promoted the most significant damages to the cell morphology and density reduction compared to untreated and herbal extract treated HTonEpiCs.

\subsection{Inhibitory effects of selected phytochemical-rich extract on LTA-PGN stimulated} secretion of pro-inflammatory biomarkers

In this study, the levels of pro-inflammatory cytokines and chemokines released into the CGM were measured by ELISA. Bacterial antigen-stimulated HTonEpiC cell model was employed. HTonEpiC were incubated with a mixture of LTA and PGN $(10 \mu \mathrm{g} / \mathrm{mL})$ to induce inflammation. Our results showed that secretion of IL-8, hBD-2, ENA-78, and CGP-2, by with the presence of all of the tested extracts, except geranium EE, were significantly declined in a dose-dependent manner. The $5 \mu \mathrm{g} / \mathrm{mL}$ extracts showed significantly higher suppression of pro-inflammatory cytokines than $1 \mu \mathrm{g} / \mathrm{mL}$ extracts $(\mathrm{p}<0.05$.). In particular, treatment of cells with $5 \mu \mathrm{g} / \mathrm{mL}$ plant extracts reduced the secretion of pro-inflammatory markers tested in a range of $1.2 \%-92.6 \%$ 
273 (Figures 3 and 4). Both the extracts of ethanol and aqueous geranium showed significant reduction

274 of cytokine, but in spite of anti-inflammatory potential, it was excluded because of its cytotoxicity,

275 which might have been responsible for the decreased levels of IL-8, hBD-2, ENA-78, and GCP-2

276 (Figures 3 and 4).

\section{4. Discussion}

278 Phytochemicals have been recognized to possess biological activities against upper respiratory 279 infections and associated inflammation (Hostanska et al. 2011; Khouya et al. 2015; Sharma et al. 280 2010). The present study was conducted to assess the anti-inflammatory properties, the secretion 281 of pro-inflammatory biomarkers by bacterial antigen-induced human epithelial cells. In streptococcus pharyngitis, host cells first recognize cell surface components of $S$. pyogenes, such as LTA and PGN and then respond to GAS through the innate immune system mediators that are involved in the inflammatory and immunological reactions (White 1999). Macrophages and mast cells induce the release of inflammatory mediators, such as COX-2, $i$ NOS, and inflammatory cytokines. Inflammatory responses have long been considered associate with the nuclear factor-kappa B (NFאB) signaling pathway (Ghosh et al. 1998) that involved in the induction of the expression of pro-inflammatory genes, including many cytokines, chemokines, and other adhesion molecules, in the inflammatory response (Ghosh et al. 1998) and the adhesion

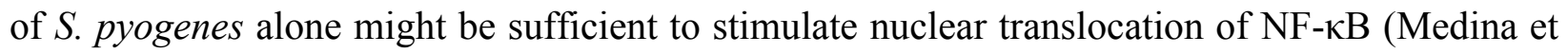
al. 2002). echinacea flower EE (45.8\%), and slippery elm EE $(44.3 \%)$ was significant $(\mathrm{P}<0.05)$ at the 
296 nimesulide (52.9\%). As well, clove AE (62.1\%), echinacea flower AE (59.8\%), oregano flowering

297 shoots AE (56.9\%), echinacea leaves AE (56.5\%) and sage leaves AE (54.8\%) showed

298 significantly higher suppression than the reference drug. These findings are in agreement with

299 other studies that showed diminished expression of various cytokines, including IL-8 by herbal

300 extracts (Hostanska et al. 2011; Sharma et al. 2010). For example, "echinaforce", a compound

301 found in EE of herb and roots of E. purpurea L. (echinacea), inhibited several bacterial inductions

302 of various cytokines, including IL-4, IL-6, IL-8, TNF- $\alpha$ and monocyte chemo-attractant protein-1,

303 in a human tracheobronchial epithelial cell line (BEAS-2B) and a human lung epithelial cell line

304 (A-549) (Sharma et al. 2010). Possible reasons for this lower activity of danshen root EE, ginger

305 EE, echinacea flower EE and slippery elm EE, may be because of the chemical constituents such

306 as flavonoids, quinones, alkaloids, triterpenes, and polyacetylates.

307 In the present study, clove, ginger, echinacea flower, oregano, thyme, and sage as well as

308 clove, ginger, and danshen EE, which were effective inhibitors of chemokine IL-8 production, also

309 potently inhibited hBD-2 production. A previous study has shown that the levels of hBD-2 strongly

310 correlated with those of increased IL-8 synthesis by lung epithelial cells in vitro (A549) and in

311 human primary bronchial epithelial cell lines (Van Wetering et al. 1997). An herbal formulation

312 (BNO 1030), an extract of seven herbal drugs, showed anti-inflammatory properties at low non-

313 cytotoxic concentrations by suppressing the secretion of IL- 8 and hBD-2 in cultured epithelial

314 A549 cells (Hostanska et al. 2011). It also explained that phenolic compounds, such as flavonoids,

315 tannins and phenolic acids present in BNO 1030, possessed cytokines suppressive capacity. The

316 significant suppression of the production of hBD-2 and IL-8 by AE of thyme, oregano, echinacea,

317 sage, clove, and ginger as well as EEs of danshen root, ginger, and clove may also have explained

318 due to their phenolic compounds. Interestingly, above-mentioned extracts showed significantly 
319 higher suppression of hBD-2 than nimesulide suggesting potential clinical applications. However, 320 this correlation between hBD-2 and IL-8 is biologically relevant because both hBD-2 and IL-8 321 inhibit cytokine produced by T helper 2 cells (Nomura et al. 2003). This finding agreed with the

322 synergistic support of hBD-2 and IL-8 expression for the T helper 1 cells, as described previously 323 (Meyer et al. 2006). The activation of NF- $\mathrm{KB}$ and AP-1 is a compulsory prerequisite for increased

324 IL-8 and IL-6 expression in epithelial cells, in response to $S$. pyogenes infection and inflammation 325 responses.

Examining the \% expression of GCP-2, it was found that EE of danshen root, clove, ginger, 327 thyme, oregano, sage, licorice, echinacea flower, and stem, as well as all the AE, account for the significant reduction of the secretion of a pro-inflammatory biomarker by LTA- and PGN-induced

329 HTonEpiC (Figures 3 and 4). Furthermore, suppression of ENA-78 (59.7\%) when treated with 5 $\mu \mathrm{g} / \mathrm{mL}$ sage root EE was shown to be significantly higher than that of $5 \mu \mathrm{g} / \mathrm{mL}$ nimesulide (41.6\%). Nevertheless, it should be noted that there was a significant reduction of ENA-78 by $5 \mu \mathrm{g} / \mathrm{mL}$ EE of clove, sage leaves, licorice root, ginger, echinacea flower and thyme, as $37.7 \%, 46.2 \%, 39.7 \%$, 39.3\%, 39.0\% and 36.7\%, respectively. Among AE, clove, echinacea leaves, and ginger showed the highest suppression $(\mathrm{P}<0.05)$ of LTA and PGN on ENA-78 secretion. Although GCP-2 335 structurally closely related to ENA-78, functionally, it can be used by both GCP-2 and IL-8 receptors to chemo-attract neutrophils (Mittal et al. 2014; Wuyts et al. 2003). Therefore, GCP-2 was shown to have higher antibacterial activity against $S$. pyogenes, compared with ENA-78 and other chemokines. The angiogenic properties of GCP-2, along with its chemotactic property, cause this enhanced antibacterial activity (Sachse et al. 2005). There was an abundant expression of IL-

3408 and GCP-2 in the surface epithelium of an acute type of tonsillitis and ENA-78 was almost undetectable (Sachse et al. 2005). This is contrary to the present results, where compared to GCP-2, 
342 the pronounced ENA-78 protein was expressed by phytochemical-rich extracts. A possible reason 343 may be the difference in the cell models used by the two studies.

Conventional therapy, steroidal and NSAID are used to treat acute inflammation. However,

345 some of those drugs exhibit several side effects (Kim et al. 2013). Therefore, alternative treatments,

346 with safer compounds, have still to be discovered. Combined treatment of thyme and oregano

347 essential oils, has been shown to limit the production of pro-inflammatory cytokines, and reduce

348 2,4,6-trinitrobenzene sulphonic acid-induced colitis in mice (Bukovska et al. 2007). The thyme

349 aromatic oil contained about $48 \%$ p-cymene and $24 \%$ of thymol, while oregano aromatic oil, which

350 contained about $55 \%$ of carvacrol, was the major active compound of these extracts (Bukovska et

al. 2007). Moreover, in vivo anti-inflammatory activities of EE of water pepper (Polygonum

hydropiper L.) (Yang et al. 2012) and EE of Chinese cinnamon (C. cassia L.)(Yu et al. 2012) suppressed the production of nitric oxide, TNF- $\alpha$, and PG E2, in LPS-activated RAW264.7 cells, along with peritoneal macrophages, in a dose-dependent manner.

Among the tested herbs, EE of danshen root, ginger, clove, echinacea flower and AE of clove, ginger, echinacea flower significantly $(\mathrm{p} \leq 0.05)$ diminished the LTA- and PGN-induced pro-inflammatory cytokines secretion. Danshen root extract was the most potent inhibitor of production of IL-8, hBD-2, ENA-78 and GCP-2. These results were consistent with the previous reports that demonstrate there are active anti-inflammatory phytochemicals of different plant extracts. For example, previous studies have reported that analgesic and anti-inflammatory activities of various phytochemicals: suppression of the transcription of pro-inflammatory mediators by [6]-gingerol of ginger (Young et al. 2005); anti-inflammatory activities in $\mathrm{H}_{2} \mathrm{O}_{2}$ stimulated macrophages by E. angustifolia L. extract (Pomari et al. 2014); and inhibition of $i$ NOS 
364 expression by carnosic acid and carnosol present in sage (S. officinalis L.) extracts (Poeckel et al. 365 2008).

Although both EE and AE from licorice root and barberry suppressed the cytokines

367 production in the present study, the percentage reductions of some cytokines were significantly

368 lower than that of ginger, clove, and echinacea extracts. However, anti-inflammatory effects of

369 licorice root extracts and their phytochemicals such as glycerrhitinic acid, glycyrrhizin,

370 licochalcone, and glycerol have been reported (Chu et al. 2012; Shin et al. 2008). The anti-

371 inflammatory activities of the major compounds present in the clove, ginger, sage as well as

372 echinacea extracts were reported earlier and this evidence elucidates the present results (Table 1).

373 The present study also found that echinacea, sage, and oregano contain a higher content of total

374 phenolic and carotenoids. The efficacious extracts or isolated phytochemicals from selected plant

375 sources can be used as an ingredient for anti-inflammatory natural health product manufacturing

376 for soothing sore throat and tonsillitis in streptococcus pharyngitis.

\section{5. Conclusion}

378 This study demonstrated that anti-inflammatory properties of danshen root EE, clove AE and EE,

379 ginger $\mathrm{AE}$ and $\mathrm{EE}$, echinacea flower $\mathrm{AE}$ and $\mathrm{EE}$, oregano leaves $\mathrm{AE}$, sage leaves $\mathrm{EE}$ or thyme

380 flowering shoot $\mathrm{AE}$ as evident by their ability to suppress protein production of pro-inflammatory

381 mediators such as IL-8, hBD-2, CGP-2 and ENA-78 in vitro. These efficacious extracts have the 382 potential to be used in developing natural health products such as phytochemicals incorporated 383 lozenges or herbal teas designed for managing pharyngitis with the aim of relieving the 384 complications associated with inflammatory conditions. Further studies are warranted to examine 385 the molecular mechanism of anti-inflammatory effect of phytochemicals from efficacious extracts. 


\section{References}

Abachi S, Lee S, and Rupasinghe HP. 2016. Molecular mechanisms of inhibition of Streptococcus species by phytochemicals. Molecules 21:1-14. 10.3390/molecules21020215

Abd El-Wahab AE, Ghareeb DA, Sarhan EE, Abu-Serie MM, and El Demellawy MA. 2013. In vitro biological assessment of Berberis vulgaris and its active constituent, berberine: antioxidants, anti-acetylcholinesterase, anti-diabetic and anticancer effects. $B M C$ Complement Altern Med 13:218. 10.1186/1472-6882-13-218

Bisno AL, Brito MO, and Collins CM. 2003. Molecular basis of group A streptococcal virulence. Lancet Infect Dis 3:191-200.

Borchers AT, Keen CL, Stern JS, and Gershwin ME. 2000. Inflammation and Native American medicine: the role of botanicals. Am J Clin Nutr 72:339-347.

Bukovska A, Cikos S, Juhas S, Il'kova G, Rehak P, and Koppel J. 2007. Effects of a combination of thyme and oregano essential oils on TNBS-induced colitis in mice. Mediators Inflamm 2007:23296. 10.1155/2007/23296

Chaieb K, Hajlaoui H, Zmantar T, Kahla-Nakbi AB, Rouabhia M, Mahdouani K, and Bakhrouf A. 2007. The chemical composition and biological activity of clove essential oil, Eugenia caryophyllata (Syzigium aromaticum L. Myrtaceae): a short review. Phytother Res 21:501-506. 10.1002/ptr.2124

Chang Q, Sun L, Zhao RH, Chow MS, and Zuo Z. 2008. Simultaneous determination of ten active components in traditional Chinese medicinal products containing both Gegen (Pueraria lobata) and Danshen (Salvia miltiorrhiza) by high-performance liquid chromatography. Phytochem Anal 19:368-375. 10.1002/pca.1063

Chu X, Ci X, Wei M, Yang X, Cao Q, Guan M, Li H, Deng Y, Feng H, and Deng X. 2012. Licochalcone a inhibits lipopolysaccharide-induced inflammatory response in vitro and in vivo. J Agric Food Chem 60:3947-3954. 10.1021/jf2051587

Cremonesi G, and Cavalieri L. 2015. Efficacy and safety of morniflumate for the treatment of symptoms associated with soft tissue inflammation. $J$ Int Med Res 43:290-302. $10.1177 / 0300060514567212$

Dennehy C. 2001. Need for additional, specific information in studies with echinacea. Antimicrob Agents Chemother 45:369-370.

Fachini-Queiroz FC, Kummer R, Estevao-Silva CF, Carvalho MD, Cunha JM, Grespan R, Bersani-Amado CA, and Cuman RK. 2012. Effects of thymol and carvacrol, constituents of Thymus vulgaris L. essential oil, on the inflammatory response. Evid Based Complement Alternat Med 2012:657026. 10.1155/2012/657026

Fournomiti M, Kimbaris A, Mantzourani I, Plessas S, Theodoridou I, Papaemmanouil V, Kapsiotis I, Panopoulou M, Stavropoulou E, Bezirtzoglou EE, and Alexopoulos A. 2015. Antimicrobial activity of essential oils of cultivated oregano (Origanum vulgare), sage (Salvia officinalis), and thyme (Thymus vulgaris) against clinical isolates of Escherichia coli, Klebsiella oxytoca, and Klebsiella pneumoniae. Microb Ecol Health Dis 26:23289. 10.3402/mehd.v26.23289

Ghannadi A, Bagherinejad M, Abedi D, Jalali M, Absalan B, and Sadeghi N. 2012. Antibacterial activity and composition of essential oils from Pelargonium graveolens L'Her and Vitex agnus-castus L. Iran J Microbiol 4:171-176. 
431

432

433

434

435

436

437

438

439

440

441

442

443

444

445

446

447

448

449

450

451

452

453

454

455

456

457

458

459

460

461

462

463

464

465

466

467

468

469

470

471

472

473

474

475

Ghosh S, May MJ, and Kopp EB. 1998. NF-kappa B and Rel proteins: evolutionarily conserved mediators of immune responses. Annu Rev Immunol 16:225-260. 10.1146/annurev.immunol.16.1.225

Goulas V, Exarchou V, Troganis AN, Psomiadou E, Fotsis T, Briasoulis E, and Gerothanassis IP. 2009. Phytochemicals in olive-leaf extracts and their antiproliferative activity against cancer and endothelial cells. Mol Nutr Food Res 53:600-608. 10.1002/mnfr.200800204

Gunathilake KD, and Rupasinghe HP. 2014. Inhibition of human low-density lipoprotein oxidation in vitro by ginger extracts. J Med Food 17:424-431. 10.1089/jmf.2013.0035

Hostanska K, Melzer J, Amon A, and Saller R. 2011. Suppression of interleukin (IL)-8 and human beta defensin-2 secretion in LPS-and/or IL-1beta-stimulated airway epithelial A549 cells by a herbal formulation against respiratory infections (BNO 1030). $J$ Ethnopharmacol 134:228-233. 10.1016/j.jep.2010.12.006

Khouya T, Ramchoun M, Hmidani A, Amrani S, Harna H, Benlyas M, Zegzouti YF, and Alem C. 2015. Anti-inflammatory, anticoagulant and antioxidant effects of aqueous extracts from Moroccan thyme varieties. Asian Pacific Journal of Tropical Biomedicin 5:636-644.

Kim SY, Chang YJ, Cho HM, Hwang YW, and Moon YS. 2013. Non-steroidal antiinflammatory drugs for the common cold. Cochrane Database Syst Rev 6:CD006362. 10.1002/14651858.CD006362.pub3

Lesley B. 2006. Slippery Elm Journal of Complementary Medicine 5:83-84.

Medina E, Anders D, and Chhatwal GS. 2002. Induction of NF-kappaB nuclear translocation in human respiratory epithelial cells by group A streptococci. Microb Pathog 33:307-313.

Meyer JE, Beier UH, Gorogh T, Schreiber S, Beck C, and Maune S. 2006. Defensin and chemokine expression patterns in the palatine tonsil: a model of their local interaction. Eur Arch Otorhinolaryngol 263:319-326. 10.1007/s00405-005-1004-4

Mittal M, Siddiqui MR, Tran K, Reddy SP, and Malik AB. 2014. Reactive oxygen species in inflammation and tissue injury. Antioxid Redox Signal 20:1126-1167. 10.1089/ars.2012.5149

Mokhber-Dezfuli N, Saeidnia S, Gohari AR, and Kurepaz-Mahmoodabadi M. 2014. Phytochemistry and pharmacology of berberis species. Pharmacogn Rev 8:8-15. 10.4103/0973-7847.125517

Nomura I, Goleva E, Howell MD, Hamid QA, Ong PY, Hall CF, Darst MA, Gao B, Boguniewicz M, Travers JB, and Leung DY. 2003. Cytokine milieu of atopic dermatitis, as compared to psoriasis, skin prevents induction of innate immune response genes. $J$ Immunol 171:3262-3269.

Park M, Bae J, and Lee DS. 2008. Antibacterial activity of [10]-gingerol and [12]-gingerol isolated from ginger rhizome against periodontal bacteria. Phytother Res 22:1446-1449. $10.1002 /$ ptr.2473

Poeckel D, Greiner C, Verhoff M, Rau O, Tausch L, Hornig C, Steinhilber D, SchubertZsilavecz M, and Werz O. 2008. Carnosic acid and carnosol potently inhibit human 5lipoxygenase and suppress pro-inflammatory responses of stimulated human polymorphonuclear leukocytes. Biochem Pharmacol 76:91-97. 10.1016/j.bcp.2008.04.013

Pomari E, Stefanon B, and Colitti M. 2014. Effect of plant extracts on $\mathrm{H}_{2} \mathrm{O}_{2}$-induced inflammatory gene expression in macrophages. J Inflamm Res 7:103-112. $10.2147 / J I R . S 61471$ 
476

477

478

479

480

481

482

483

484

485

486

487

488

489

490

491

492

493

494

495

496

497

498

499

500

501

502

503

504

505

506

507

508

509

510

511

512

513

514

515

516

517

518

519

520

521

Rani B, Kachhawa G, R., Yadav RK, Chauhan V, and Maheshwari R. 2012. Phytochemical effectiveness of clove oil: a review. Int $J$ of Res in Pharmacology and

Pharmacotherapeutics 1:230-233. 10.1016/j.pedn.2011.03.011

Ricciotti E, and FitzGerald GA. 2011. Prostaglandins and inflammation. Arterioscler Thromb Vasc Biol 31:986-1000. 10.1161/ATVBAHA.110.207449

Rivera S, and Canela R. 2012. Influence of sample processing on the analysis of carotenoids in maize. Molecules 17:11255-11268. 10.3390/molecules170911255

Rock KL, Latz E, Ontiveros F, and Kono H. 2010. The sterile inflammatory response. Annu Rev Immunol 28:321-342. 10.1146/annurev-immunol-030409-101311

Rupasinghe HPV, Huber GM, Embree GC, and Forsline PL. 2010. Red-fleshed apple as a source for functional beverages. Can J Plant Sc 90:95-100. 10.1021/jf903162k

Sachse F, Ahlers F, Stoll W, and Rudack C. 2005. Neutrophil chemokines in epithelial inflammatory processes of human tonsils. Clin Exp Immunol 140:293-300. 10.1111/j.1365-2249.2005.02773.x

Schams SC, and Goldman RD. 2012. Steroids as adjuvant treatment of sore throat in acute bacterial pharyngitis. Can Fam Physician 58:52-54.

Sharma SM, Anderson M, Schoop SR, and Hudson JB. 2010. Bactericidal and anti-inflammatory properties of a standardized Echinacea extract (Echinaforce): dual actions against respiratory bacteria. Phytomedicine 17:563-568. 10.1016/j.phymed.2009.10.022

Shin EM, Zhou HY, Guo LY, Kim JA, Lee SH, Merfort I, Kang SS, Kim HS, Kim S, and Kim YS. 2008. Anti-inflammatory effects of glycyrol isolated from Glycyrrhiza uralensis in LPS-stimulated RAW264.7 macrophages. Int Immunopharmacol 8:1524-1532. 10.1016/j.intimp.2008.06.008

Teixeira B, Marques A, Ramos C, Serrano C, Matos O, Neng NR, Nogueira JM, Saraiva JA, and Nunes ML. 2013. Chemical composition and bioactivity of different oregano (Origanum vulgare) extracts and essential oil. J Sci Food Agric 93:2707-2714. 10.1002/jsfa.6089

Van Wetering S, Mannesse-Lazeroms SP, Van Sterkenburg MA, Daha MR, Dijkman JH, and Hiemstra PS. 1997. Effect of defensins on interleukin-8 synthesis in airway epithelial cells. Am J Physiol 272:L888-896.

Vroling AB, Fokkens WJ, and van Drunen CM. 2008. How epithelial cells detect danger: aiding the immune response. Allergy 63:1110-1123.

White M. 1999. Mediators of inflammation and the inflammatory process. J Allergy Clin Immunol 103:S378-381.

Wuyts A, Struyf S, Gijsbers K, Schutyser E, Put W, Conings R, Lenaerts JP, Geboes K, Opdenakker G, Menten P, Proost P, and Van Damme J. 2003. The CXC chemokine GCP-2/CXCL6 is predominantly induced in mesenchymal cells by interleukin-1beta and is down-regulated by interferon-gamma: comparison with interleukin-8/CXCL8. Lab Invest 83:23-34.

Yang Y, Yu T, Jang HJ, Byeon SE, Song SY, Lee BH, Rhee MH, Kim TW, Lee J, Hong S, and Cho JY. 2012. In vitro and in vivo anti-inflammatory activities of Polygonum hydropiper methanol extract. J Ethnopharmacol 139:616-625. 10.1016/j.jep.2011.12.003

Young HY, Luo YL, Cheng HY, Hsieh WC, Liao JC, and Peng WH. 2005. Analgesic and antiinflammatory activities of [6]-gingerol. J Ethnopharmacol 96:207-210. 10.1016/j.jep.2004.09.009

Yu T, Lee S, Yang WS, Jang HJ, Lee YJ, Kim TW, Kim SY, Lee J, and Cho JY. 2012. The ability of an ethanol extract of Cinnamomum cassia to inhibit Src and spleen tyrosine 
kinase activity contributes to its anti-inflammatory action. J Ethnopharmacol 139:566- 


\begin{tabular}{|c|c|c|c|c|}
\hline Plant Name & Family & $\begin{array}{l}\text { Parts } \\
\text { used }\end{array}$ & Major phytochemicals & References \\
\hline $\begin{array}{l}\text { Barberry } \\
\text { (Berberis vulgaris L.) }\end{array}$ & Berberidaceae & $\mathrm{R}$ & $\begin{array}{l}\text { Berberine, Berbamine, 5- } \\
\text { Methoxyhydnocarpin, Berlambine, } \\
\text { Jatrorrhizine, Palmatine, Quercetin, Rutin } \\
\text { and Oxyberberine }\end{array}$ & $\begin{array}{l}\text { (Abd El-Wahab et } \\
\text { al. 2013; Mokhber- } \\
\text { Dezfuli et al. 2014) }\end{array}$ \\
\hline $\begin{array}{l}\text { Clove } \\
\text { (Syzygium aromaticum L.) }\end{array}$ & Myrtaceae & FB & $\begin{array}{l}\text { Eugenol, Eugenyl acetate, } \beta \text {-Caryophyllene, } \\
\alpha \text {-Humulene, } \beta \text {-Ocimene, Caryophyllene } \\
\text { oxide, } \alpha \text {-Copaene and p-Allyl phenol }\end{array}$ & $\begin{array}{l}\text { (Chaieb et al. 2007; } \\
\text { Rani et al. 2012) }\end{array}$ \\
\hline $\begin{array}{l}\text { Echinacea/purple cone flower } \\
\text { (Echinacea purpurea L.) }\end{array}$ & Asteraceae & $\begin{array}{l}\mathrm{L} \\
\mathrm{S} \\
\mathrm{F}\end{array}$ & $\begin{array}{l}\text { Caftaric acid, Chlorogenic acid, Caffeic acid, } \\
\text { Cynarin, Echinacoside, Cichoric acid, } \\
\text { Quercetin and Kaempferol }\end{array}$ & $\begin{array}{l}\text { (Dennehy 2001; } \\
\text { Sharma et al. 2010) }\end{array}$ \\
\hline $\begin{array}{l}\text { Geranium } \\
\text { (Pelargonium graveolens L.) }\end{array}$ & Geraniaceae & $\mathrm{L}$ & Citronellol, Citronellyl formate and Geraniol & $\begin{array}{l}\text { (Ghannadi et al. } \\
\text { 2012) }\end{array}$ \\
\hline $\begin{array}{l}\text { Ginger } \\
\text { (Zingiber officinale L.) }\end{array}$ & Zingiberaceae & $\mathrm{Rh}$ & $\begin{array}{l}\text { Gingerol, Galanolactone, Ginerdiol, } \\
\text { Geranial, } \alpha \text {-Zingiberene, Oleoresin, and } \\
\text { Zingerone }\end{array}$ & $\begin{array}{l}\text { (Gunathilake \& } \\
\text { Rupasinghe 2014; } \\
\text { Young et al. 2005) }\end{array}$ \\
\hline $\begin{array}{l}\text { Licorice } \\
\text { (Glycyrrhiza glabra L.) }\end{array}$ & Fabaceae & $\mathrm{R}$ & $\begin{array}{l}\text { Glycyrrhizin, Glabridin, Liquirtin, } \\
\text { Licoflavan, Narigenin and Asparegene }\end{array}$ & $\begin{array}{l}\text { (Chu et al. 2012; } \\
\text { Shin et al. 2008) }\end{array}$ \\
\hline $\begin{array}{l}\text { Olive } \\
\text { (Olea europeus L.) }\end{array}$ & Oleaceae & $\mathrm{L}$ & $\begin{array}{l}\text { Hydroxytyrosol, Luteolin-7-O-glucoside, } \\
\text { Luteolin-4-O-glucoside, Oleuropein, and } \\
\text { Hydroxytyrosol acetate }\end{array}$ & (Goulas et al. 2009) \\
\hline Oregano (Origanum vulgare L.) & Lamiaceae & FS & $\begin{array}{l}\text { Carvacrol, p-Cymene, Borneol, Thymol, } \\
\text { Linalool, Linlyl acetate, Terpinene-4-ol, } \\
\text { Rosmarinic acid, Thymohydroquinone and } \\
\text { Naringin }\end{array}$ & $\begin{array}{l}\text { (Fournomiti et al. } \\
\text { 2015; Teixeira et al. } \\
\text { 2013) }\end{array}$ \\
\hline Sage (Salvia officinalis L.) & Lamiaceae & $\mathrm{L}$ & $\begin{array}{l}\text { 1,8-Cineole, } p \text {-Cymene, Camphor, borneol, } \\
\alpha \text {-Thujone, } \beta \text {-Pinene, } \alpha \text {-Humulene, trans- } \\
\text { Caryophyllene, } \beta \text {-Thujone and Myrcene }\end{array}$ & $\begin{array}{l}\text { (Fournomiti et al. } \\
\text { 2015), (Poeckel et } \\
\text { al. 2008) }\end{array}$ \\
\hline $\begin{array}{l}\text { Danshen (Salvia miltiorrhiza } \\
\text { Bunge.) }\end{array}$ & Lamiaceae & $\mathrm{R}$ & $\begin{array}{l}\text { danshensu, protocatechuic aldehyde, } \\
\text { salvianolic acid B, cryptotanshinone, }\end{array}$ & (Chang et al. 2008) \\
\hline
\end{tabular}


tanshinone I and tanshinone IIa

\begin{tabular}{|c|c|c|c|c|}
\hline $\begin{array}{l}\text { Slippery elm (Ulmus rubra } \\
\text { Muhl) }\end{array}$ & Ulmaceae & IB & $\begin{array}{l}\text { Oleanolic acid, Ursolic acid, Uvaol, } \\
\text { Betulinic acid, Botulin, } \beta \text {-Arotene, } \beta \text { - } \\
\text { Sitosterol and Citrostadienol }\end{array}$ & (Lesley 2006) \\
\hline Thyme (Thymus vulgaris L.) & Lamiaceae & FS & $\begin{array}{l}\text { Thymol, } \gamma \text {-Terpinene, } p \text {-Cymene, Mycrene, } \\
\alpha \text {-Pinene , } \alpha \text {-Thujone, } \alpha \text {-Terpinene, } \\
\text { Carvacrol , } 1,8 \text { Cineole, Methyl ether, } \\
\text { Linalool, } \gamma \text {-Terpinene and } \alpha \text {-Terpineol }\end{array}$ & $\begin{array}{l}\text { (Fachini-Queiroz et } \\
\text { al. 2012; Fournomiti } \\
\text { et al. 2015) }\end{array}$ \\
\hline
\end{tabular}

* F: flowers, FB: flowering buds, IB: inner bark, FS: flowering shoots, Rh: rhizome, R: roots, L: leaves, and S: stem. 
Table 2: Extraction yield, total phenolic content, and total carotenoids content of the examined plant extracts.

\begin{tabular}{|c|c|c|c|c|c|c|c|}
\hline \multirow{2}{*}{ Plant Name } & \multirow{2}{*}{$\begin{array}{c}\text { Parts } \\
\text { used }\end{array}$} & \multicolumn{2}{|c|}{$\begin{array}{l}\text { Extract yield (\%) } \\
\text { (DW basis) }\end{array}$} & \multicolumn{2}{|c|}{$\begin{array}{l}\text { Total phenolics } \\
\text { (mg GAE/g DW) }\end{array}$} & \multicolumn{2}{|c|}{$\begin{array}{c}\text { Total carotenoids } \\
(\mu \mathrm{g} / \mathrm{g} \mathrm{DW})\end{array}$} \\
\hline & & $\mathbf{E E}$ & $\mathbf{A E}$ & $\mathbf{E E}$ & $\mathbf{A E}$ & $\mathbf{E E}$ & $\mathbf{A E}$ \\
\hline Barberry & $\mathrm{R}$ & $1.9 \pm 0.0^{\mathrm{g}}$ & $5.9 \pm 0.1^{\mathrm{e}}$ & $2.6 \pm 0.05^{f}$ & $2.3 \pm 0.1^{\mathrm{e}}$ & $494.9 \pm 4.0^{\mathrm{e}}$ & $31.6 \pm .7^{\mathrm{e}}$ \\
\hline Clove & FB & $21.3 \pm 1.2^{\mathrm{b}}$ & $24.6 \pm 0.4^{\mathrm{bcd}}$ & $19.1 \pm 0.0^{\mathrm{a}}$ & $16.0 \pm 0.2^{\mathrm{a}}$ & $92.1 \pm 0.2^{\mathrm{hi}}$ & NA \\
\hline \multirow[t]{3}{*}{ Echinacea } & $\mathrm{L}$ & $7.1 \pm 0.3^{\mathrm{efg}}$ & $31.5 \pm 1.7^{\mathrm{a}}$ & $1.7 \pm 0.0^{\mathrm{fg}}$ & $2.1 \pm 0.1^{\mathrm{e}}$ & $6248.8 \pm 11.6^{\mathrm{a}}$ & $24.3 \pm 0.9^{\mathrm{ef}}$ \\
\hline & S & $5.6 \pm 0.0^{\mathrm{fg}}$ & $18.9 \pm 0.4^{\mathrm{cd}}$ & $1.1 \pm 0.3^{\mathrm{g}}$ & $1.2 \pm 0.1^{\mathrm{f}}$ & $388.0 \pm 3.7^{\mathrm{f}}$ & $147.0 \pm 2.1^{\mathrm{d}}$ \\
\hline & $\mathrm{F}$ & $6.8 \pm 0.1^{\mathrm{efg}}$ & $20.3 \pm 1.3^{\mathrm{d}}$ & $1.0 \pm 0.0^{\mathrm{g}}$ & $2.6 \pm 0.1^{\mathrm{e}}$ & $292.6 \pm 0.6^{\mathrm{g}}$ & $2.0 \pm 0.0^{\mathrm{h}}$ \\
\hline Geranium & $\mathrm{L}$ & $9.3 \pm 0.1^{\mathrm{def}}$ & $29.0 \pm 2.2^{\mathrm{ab}}$ & $7.1 \pm 0.4^{\mathrm{cd}}$ & $10.6 \pm 0.3^{b}$ & $2505.8 \pm 8.4^{b}$ & $18.6 \pm 3.4^{\mathrm{fg}}$ \\
\hline Ginger & $\mathrm{Rh}$ & $19.6 \pm 0.9^{\mathrm{bc}}$ & $19.9 \pm 0.7^{\mathrm{d}}$ & $6.9 \pm 0.5^{\mathrm{cd}}$ & $0.5 \pm 0.4^{\mathrm{f}}$ & $455.0 \pm 19.7^{\mathrm{ef}}$ & $7.8 \pm 0.2^{\mathrm{gh}}$ \\
\hline Licorice & $\mathrm{R}$ & $39.0 \pm 1.9^{\mathrm{a}}$ & $19.5 \pm 0.2^{\mathrm{d}}$ & $4.6 \pm 0.0^{\mathrm{e}}$ & $2.8 \pm 0.1^{\mathrm{e}}$ & $157.4 \pm 3.9^{\mathrm{h}}$ & $237.3 \pm 0.4^{\mathrm{c}}$ \\
\hline Olive & $\mathrm{L}$ & $22.2 \pm 2.7^{\mathrm{bc}}$ & $24.2 \pm 2.3^{\mathrm{bcd}}$ & $5.3 \pm 0.0^{\mathrm{e}}$ & $5.7 \pm 0.2^{\mathrm{c}}$ & $235.6 \pm 2.3^{\mathrm{g}}$ & $677.6 \pm 4.2^{\mathrm{a}}$ \\
\hline Oregano & FS & $14.5 \pm 0.5^{\mathrm{cd}}$ & $8.2 \pm 0.2^{\mathrm{e}}$ & $9.2 \pm 0.5^{\mathrm{b}}$ & $9.8 \pm 0.1^{\mathrm{b}}$ & $2032.4 \pm 24.7^{\mathrm{d}}$ & $10.6 \pm 0.3^{\mathrm{gh}}$ \\
\hline Sage & $\mathrm{L}$ & $8.9 \pm 0.9^{\mathrm{def}}$ & $19.8 \pm 1.1^{\mathrm{d}}$ & $5.2 \pm 0.1^{\mathrm{e}}$ & $4.1 \pm 0.1^{\mathrm{d}}$ & $2066.9 \pm 11.8^{d}$ & $25.9 \pm 1.0^{\mathrm{ef}}$ \\
\hline Danshen & $\mathrm{R}$ & NA & NA & $10.0 \pm 0.5^{b}$ & NA & NA & NA \\
\hline Slippery elm & IB & $7.6 \pm 0.3^{\mathrm{ef}}$ & $7.1 \pm 0.1^{\mathrm{e}}$ & $7.5 \pm 0.1^{\mathrm{c}}$ & $1.9 \pm 0.1^{\mathrm{e}}$ & $72.7 \pm 6.2^{\mathrm{i}}$ & $400.5 \pm 3.5^{b}$ \\
\hline Thyme & FS & $10.5 \pm 0.4^{\mathrm{de}}$ & $18.6 \pm 1.1^{\mathrm{d}}$ & $6.0 \pm 0.2^{\mathrm{de}}$ & $5.1 \pm 0.1^{\mathrm{c}}$ & $2373.2 \pm 27.7^{\mathrm{c}}$ & $401.5 \pm 4.9^{b}$ \\
\hline
\end{tabular}

* Means \pm SEM $(n=3)$ of different extracts analyzed individually in triplicate. Different superscript letters within the same column indicate significant differences of means among extraction solvents used in the study. AE: aqueous extracts, DW: dry weight of extracts, EE: ethanol extracts, GAE: Gallic acid equivalents, NA: not analyzed, TE: Toluene equivalents, F: flowers, FB: flowering buds, IB: inner bark, FS: flowering shoots, Rh: rhizome, R: roots, L: leaves, and S: stem. 
Table 3: Effect of concentration of the extracts on percentage viability of human tonsil epithelial cells.

\begin{tabular}{|c|c|c|c|c|c|c|}
\hline \multirow[t]{3}{*}{ Test materials } & \multicolumn{6}{|c|}{ Cell viability (\%) } \\
\hline & \multicolumn{2}{|c|}{$0.5 \mu \mathrm{g} / \mathrm{mL}$} & \multicolumn{2}{|c|}{$1 \mu \mathrm{g} / \mathrm{mL}$} & \multicolumn{2}{|c|}{$5 \mu \mathrm{g} / \mathrm{mL}$} \\
\hline & $\mathbf{A E}$ & $\mathbf{E E}$ & $\mathbf{A E}$ & EE & $\mathbf{A E}$ & EE \\
\hline Licorice $\mathrm{R}$ & $96.4 \pm 0.9^{\mathrm{a}}$ & $99.1 \pm 0.9^{\mathrm{a}}$ & $97.1 \pm 0.5^{\mathrm{a}}$ & $98.0 \pm 0.9^{\mathrm{a}}$ & $80.7 \pm 1.0^{\mathrm{c}}$ & $98.4 \pm 0.9^{\mathrm{a}}$ \\
\hline Sage L & $98.7 \pm 0.6^{\mathrm{a}}$ & $99.8 \pm 0.2^{\mathrm{a}}$ & $98.7 \pm 0.5^{\mathrm{a}}$ & $96.2 \pm 3.4^{\mathrm{a}}$ & $89.4 \pm 2.9^{b}$ & $86.2 \pm 0.6^{\mathrm{c}}$ \\
\hline Echinacea $\mathrm{S}$ & $97.8 \pm 0.6^{\mathrm{a}}$ & $82.8 \pm 2.1^{\mathrm{c}}$ & $98.0 \pm 0.5^{\mathrm{a}}$ & $95.8 \pm 2.1^{\mathrm{a}}$ & $84.2 \pm 2.0^{\mathrm{c}}$ & $83.0 \pm 1.2^{\mathrm{c}}$ \\
\hline Echinacea $\mathrm{F}$ & $98.2 \pm 0.3^{\mathrm{a}}$ & $97.1 \pm 1.2^{\mathrm{a}}$ & $98.1 \pm 0.0^{\mathrm{a}}$ & $96.1 \pm 1.7^{\mathrm{a}}$ & $99.1 \pm 1.8^{\mathrm{a}}$ & $97.1 \pm 0.6^{\mathrm{a}}$ \\
\hline Oregano FS & $99.3 \pm 1.1^{\mathrm{a}}$ & $96.9 \pm 1.1^{\mathrm{a}}$ & $97.1 \pm 0.0^{\mathrm{a}}$ & $96.9 \pm 0.6^{\mathrm{a}}$ & $97.4 \pm 0.6^{\mathrm{a}}$ & $86.9 \pm 0.6 .^{\mathrm{c}}$ \\
\hline Thyme FS & $99.1 \pm 0.6^{\mathrm{a}}$ & $95.6 \pm 1.8^{\mathrm{ab}}$ & $96.1 \pm 0.6^{\mathrm{a}}$ & $96.6 \pm 1.8^{\mathrm{ab}}$ & $98.9 \pm 0.5^{\mathrm{a}}$ & $95.6 \pm 1.2^{\mathrm{a}}$ \\
\hline Barberry R & $98.1 \pm 0.6^{\mathrm{a}}$ & $97.5 \pm 0.4^{\mathrm{a}}$ & $97.0 \pm 0.7^{\mathrm{a}}$ & $95.5 \pm 0.2^{\mathrm{ab}}$ & $96.0 \pm 0.3^{\mathrm{a}}$ & $97.5 \pm 0.6^{\mathrm{a}}$ \\
\hline Slippery elm IB & $99.0 \pm 0.8^{\mathrm{a}}$ & $93.4 \pm 0.6^{b}$ & $97.0 \pm 0.6^{\mathrm{a}}$ & $89.7 \pm 0.6^{\mathrm{b}}$ & $97.6 \pm 1.1^{\mathrm{a}}$ & $82.7 \pm 0.6^{\mathrm{c}}$ \\
\hline Clove FB & $98.4 \pm 0.0^{\mathrm{a}}$ & $97.5 \pm 1.1^{\mathrm{a}}$ & $98.9 \pm 0.2^{\mathrm{a}}$ & $96.5 \pm 1.1^{\mathrm{ab}}$ & $98.3 \pm 0.6^{\mathrm{a}}$ & $97.5 \pm 0.7^{\mathrm{a}}$ \\
\hline Ginger Rh & $98.1 \pm 0.0^{\mathrm{a}}$ & $98.9 \pm 0.3^{\mathrm{a}}$ & $98.4 \pm 0.5^{\mathrm{a}}$ & $98.9 \pm 0.9^{a}$ & $98.7 \pm 0.3^{\mathrm{a}}$ & $98.9 \pm 0.7^{\mathrm{a}}$ \\
\hline Olive L & $97.0 \pm 0.9^{\mathrm{a}}$ & $96.8 \pm 0.9^{\mathrm{ab}}$ & $96.0 \pm 0.9^{\mathrm{a}}$ & $98.8 \pm 0.9^{\mathrm{a}}$ & $96.2 \pm 0.6^{\mathrm{a}}$ & $98.8 \pm 1.2^{\mathrm{a}}$ \\
\hline Geranium L & $98.2 \pm 0.7^{\mathrm{a}}$ & $85.1 \pm 1.1^{\mathrm{c}}$ & $99.0 \pm 0.6^{\mathrm{a}}$ & $46.1 \pm 1.1^{\mathrm{de}}$ & $93.1 \pm 0.6^{\mathrm{ab}}$ & $41.1 \pm 0.0^{\mathrm{e}}$ \\
\hline Echinacea L & $98.0 \pm 0.8^{\mathrm{a}}$ & $97.3 \pm 0.8^{\mathrm{a}}$ & $96.3 \pm 0.9^{\mathrm{a}}$ & $97.9 \pm 0.9^{\mathrm{a}}$ & $97.1 \pm 0.75^{\mathrm{a}}$ & $97.9 \pm 0.3^{\mathrm{a}}$ \\
\hline Danshen R & ND & $95.9 \pm 0.6^{\mathrm{ab}}$ & ND & $98.9 \pm 0.6^{\mathrm{a}}$ & ND & $98.9 \pm 0.6^{\mathrm{a}}$ \\
\hline Nimesulide & $98.0 \pm 0.9^{\mathrm{a}}$ & $97.4 \pm 0.5^{\mathrm{a}}$ & $98.1 \pm 0.8^{\mathrm{a}}$ & $95.8 \pm 1.0^{\mathrm{ab}}$ & $96.0 \pm 0.6^{\mathrm{a}}$ & $95.8 \pm 1.0^{\mathrm{ab}}$ \\
\hline
\end{tabular}

* Cells were treated with various concentrations of the test materials for $24 \mathbf{h}$. Cell viability (\%) was calculated relative to the control of $\mathbf{0 . 0 5 \%}$ DMSO. Values of the same column are expressed as mean \pm SEM $(n=3)$. a-g: The value with different letters indicates the significant difference determined by Tukey's test $(p \leq 0.05)$. ND: not determined, F: flowers, FB: flower bud, FS: flowering shoots, IB: inner bark, L: leaves, Rh: rhizome, R: roots, and S: stem. 


\section{Figure Captions:}

543 Figure 1: Morphology of inflammation-induced tonsil epithelial cells treated with the ethanol

544 extracts. The LTA+PGN-induced cells were incubated with $5 \mu \mathrm{g} / \mathrm{mL}$ of the extracts for $24 \mathrm{~h}$. All 545 images were obtained at a magnification of $\times$ 40. (a) Media control; (b) $0.05 \%$ DMSO control; (c)

$54610 \mu \mathrm{g} / \mathrm{mL}$ LTA and PGN; (d) Licorice root; (e) Sage leaves; (f) Echinacea stem; (g) Echinacea 547 flower; (h) Oregano shoots; (i) Thyme shoots; (j) Barberry root; (k) Slippery elm inner bark; (1)

548 Clove flower bud; (m) Ginger rhizome; (n) Olive leaves; (o) Geranium leaves; (p) Echinacea 549 leaves; (q) Danshen root and (r) Nimesulide.

Figure 2: Morphology of inflammation-induced tonsil epithelial cells treated with the aqueous

552 extracts. The LTA+PGN-induced cells were incubated with $5 \mu \mathrm{g} / \mathrm{mL}$ of the extracts for $24 \mathrm{~h}$. All 553 images were obtained at a magnification of $\times$ 40. (a) Media control; (b) 0.05\% DMSO control; (c)

$55410 \mu \mathrm{g} / \mathrm{mL}$ LTA and PGN; (d) Licorice root; (e) Sage leaves; (f) Echinacea stem; (g) Echinacea 555 flower; (h) Oregano shoots; (i) Thyme shoots; (j) Barberry root; (k) Slippery elm inner bark; (1) 556 Clove flower bud; (m) Ginger rhizome; (n) Olive leaves; (o) Geranium leaves; (p) Echinacea 557 leaves and (q) Nimesulide.

558

559

560

561

562

563

564
Figure 3: Secretion of pro-inflammatory proteins by tonsil epithelial cells treated with the ethanol extracts. The inflammation of human tonsil epithelial cells was stimulated by a mixture of LTA + PGN, and then incubated with selected phytochemical-rich ethanol extracts. Data were expressed as mean $\pm \operatorname{SEM}(n=3)$. Groups sharing different letters showed a significant difference (Tukey's test, $\mathrm{p} \leq$ 0.05). IL-8, interleukin-8; hBD-2, human beta defensin-2; GCP-2, granulocyte chemotactic protein-2; ENA-78, epithelial-derived neutrophil activating protein-78; LTA, 
565 lipoteichoic acid; PGN, peptidoglycan; F: flowers; FB: flower bud; FS: flowering shoots; IB: inner

566 bark; L: leaves; Rh: rhizome; R: roots; S: stem.

567

568 Figure 4: Secretion of pro-inflammatory proteins by tonsil epithelial cells treated with the aqueous

569 extracts. The inflammation of human tonsil epithelial cells was stimulated by a mixture of LTA +

570 PGN, and then incubated with selected phytochemical-rich ethanol extracts. Data were expressed

571 as mean \pm SEM (n=3). Groups sharing different letters showed a significant difference (Tukey's

572 test, $\mathrm{p} \leq$ 0.05). IL-8, interleukin-8; hBD-2, human beta defensin-2; GCP-2, granulocyte

573 chemotactic protein-2; ENA-78, epithelial-derived neutrophil activating protein-78; LTA,

574 lipoteichoic acid; PGN, peptidoglycan; F: flowers; FB: flower bud; FS: flowering shoots; IB: inner

575 bark; L: leaves; Rh: rhizome; R: roots; S: stem. 


\section{Figure 1}

577

578

579

580

581

582

583

584

585

586

587

588

589

590

591

592

593

594
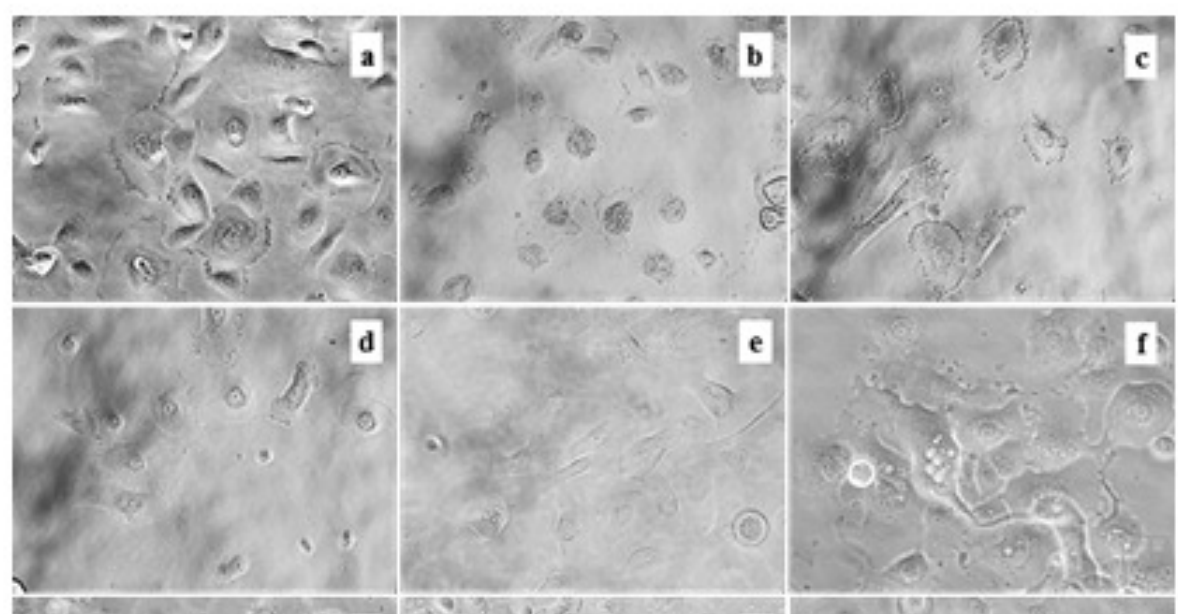

3

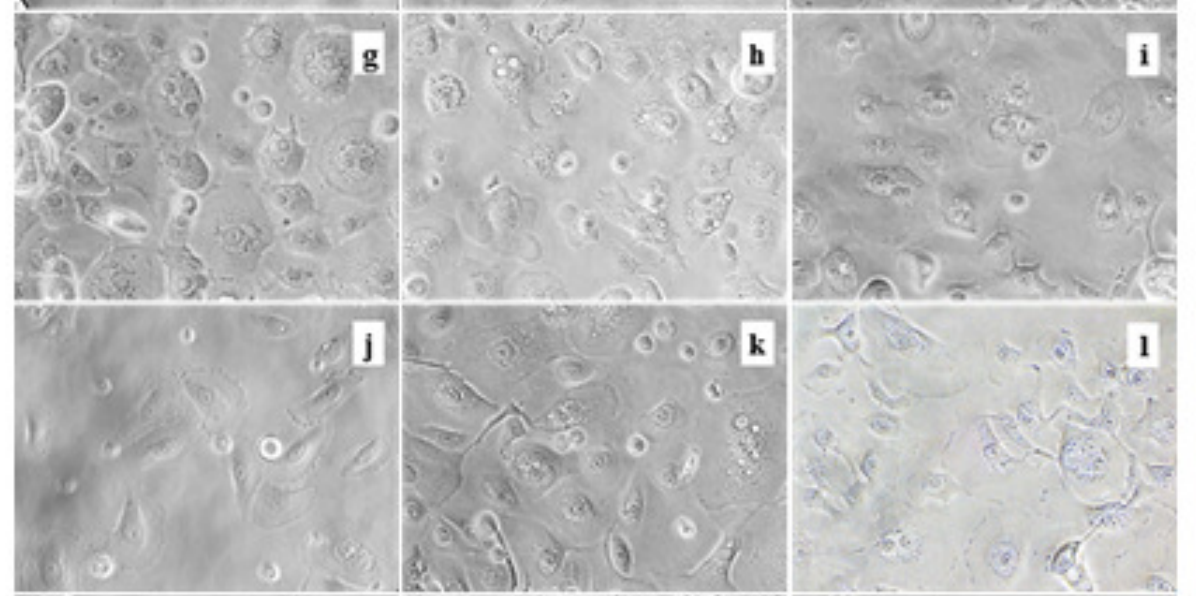

9

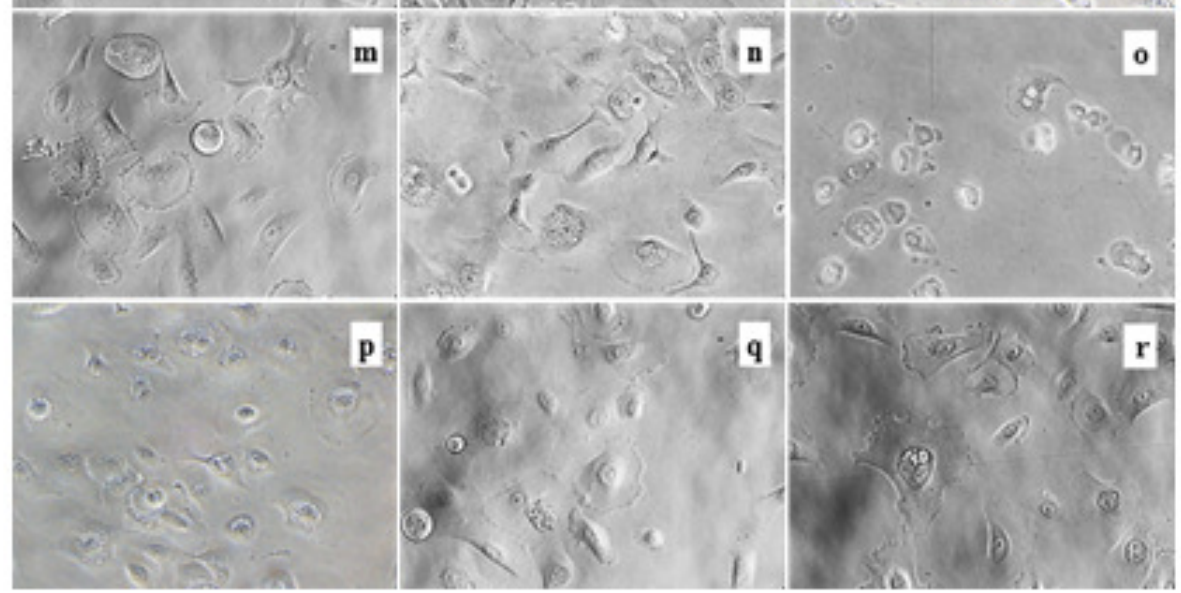

595

596

597 
599 Figure 2

600

601

602

603

604

605

606

607

608

609

610

611

612

613

614

615

616
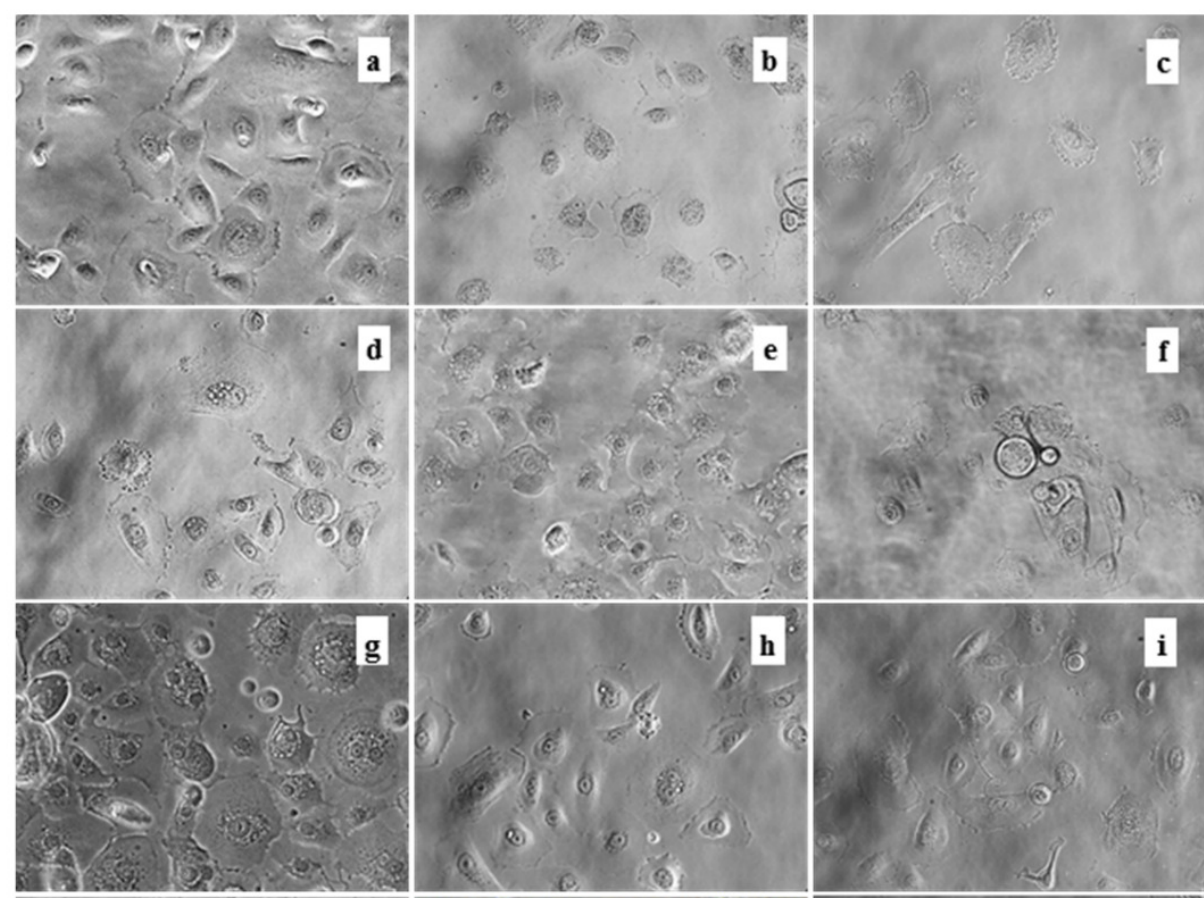

$(1$
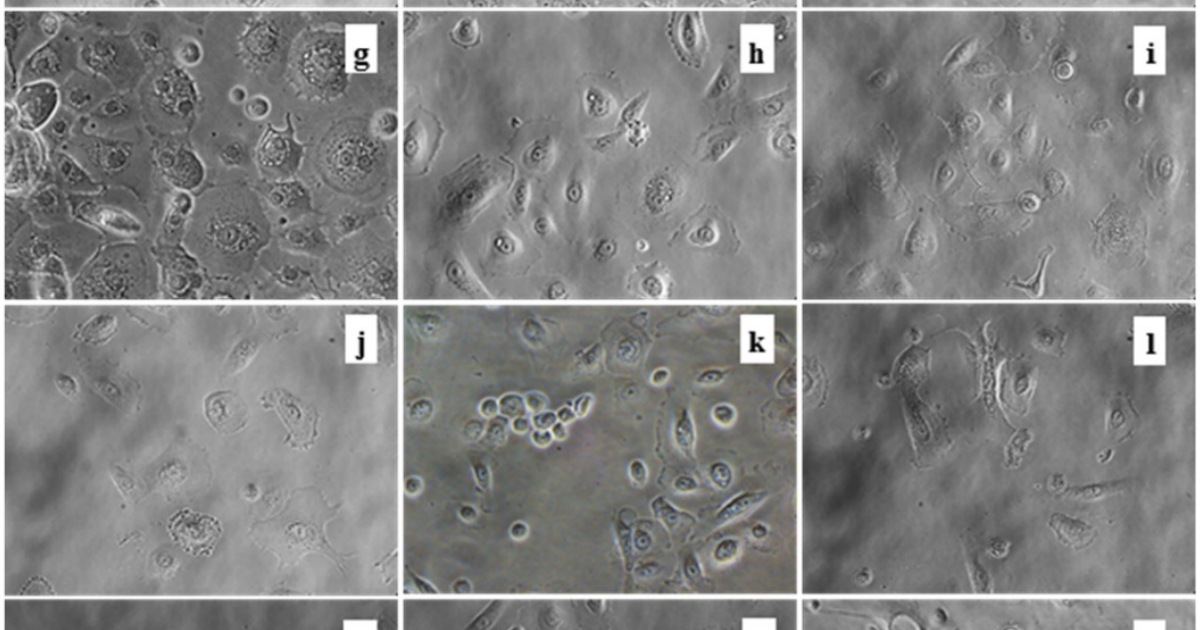

o
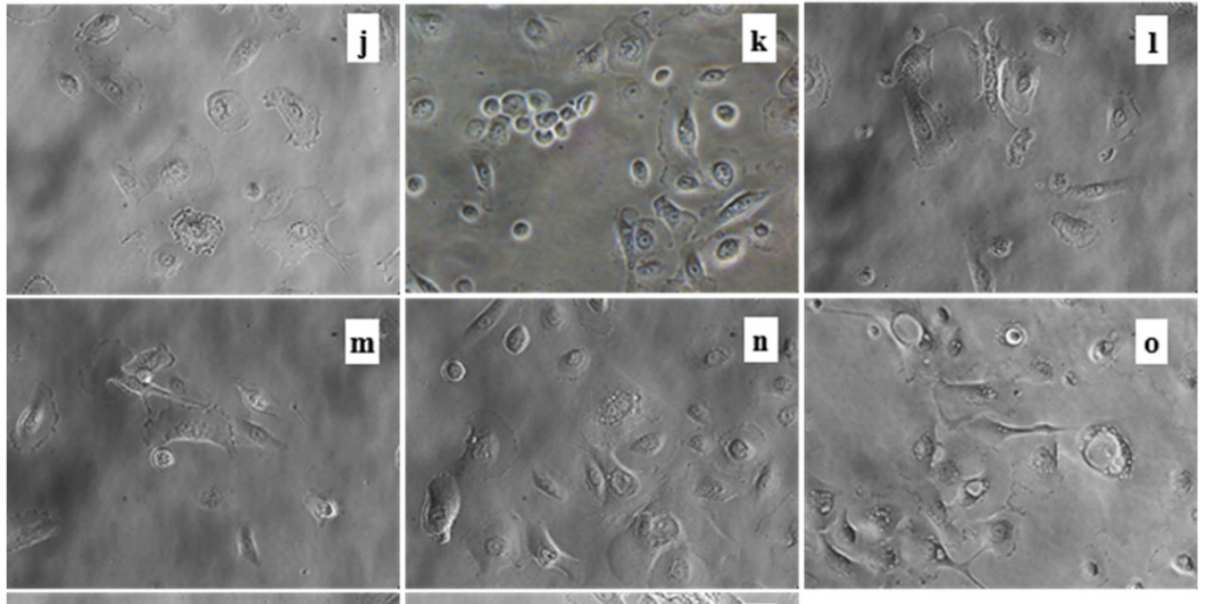

617

618

(3)

619

620 


\section{Figure 3}

622
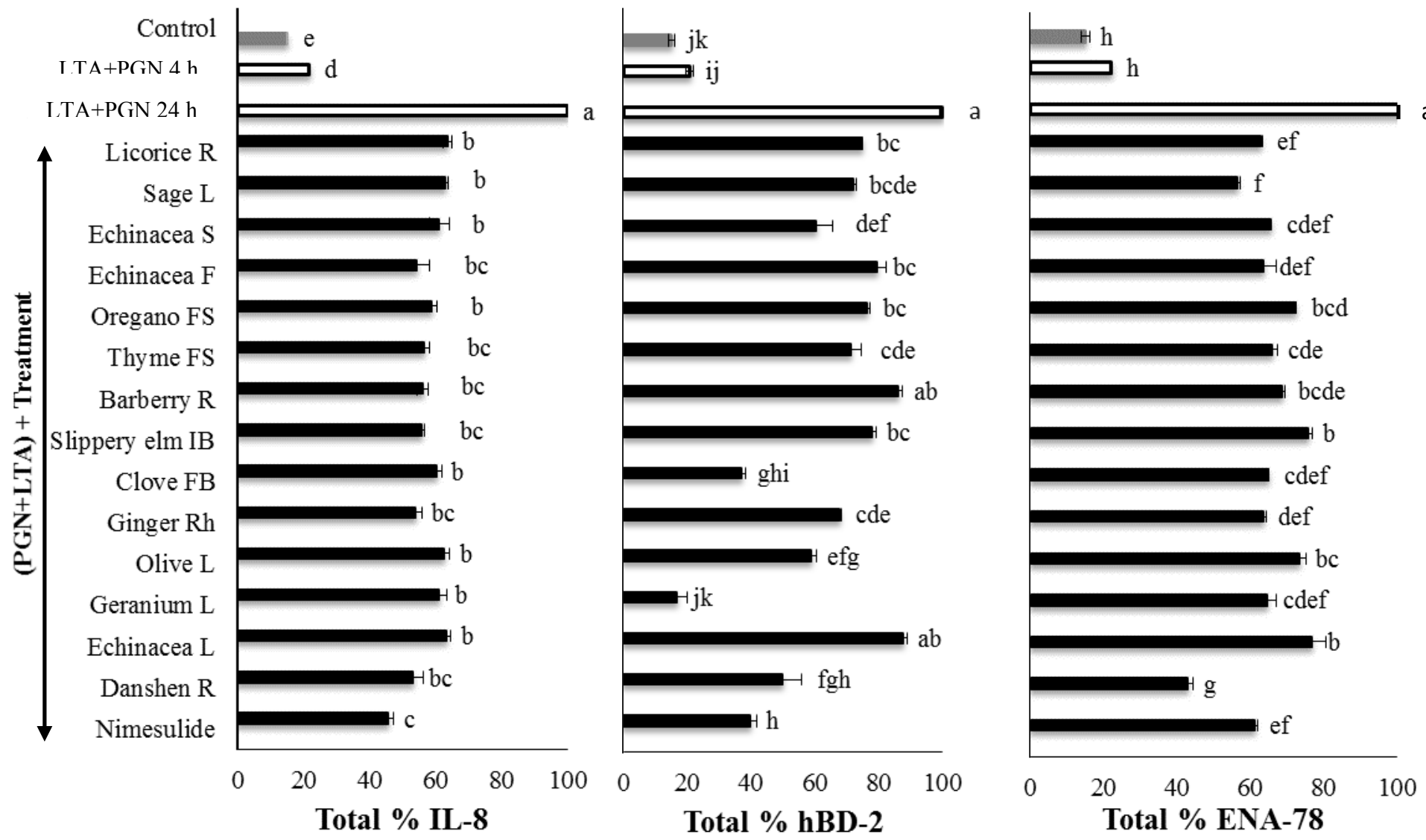

- $5 \mu \mathrm{g} / \mathrm{mL} \quad \square 10 \mu \mathrm{g} / \mathrm{mL} \quad$ DMSO 
Figure 4
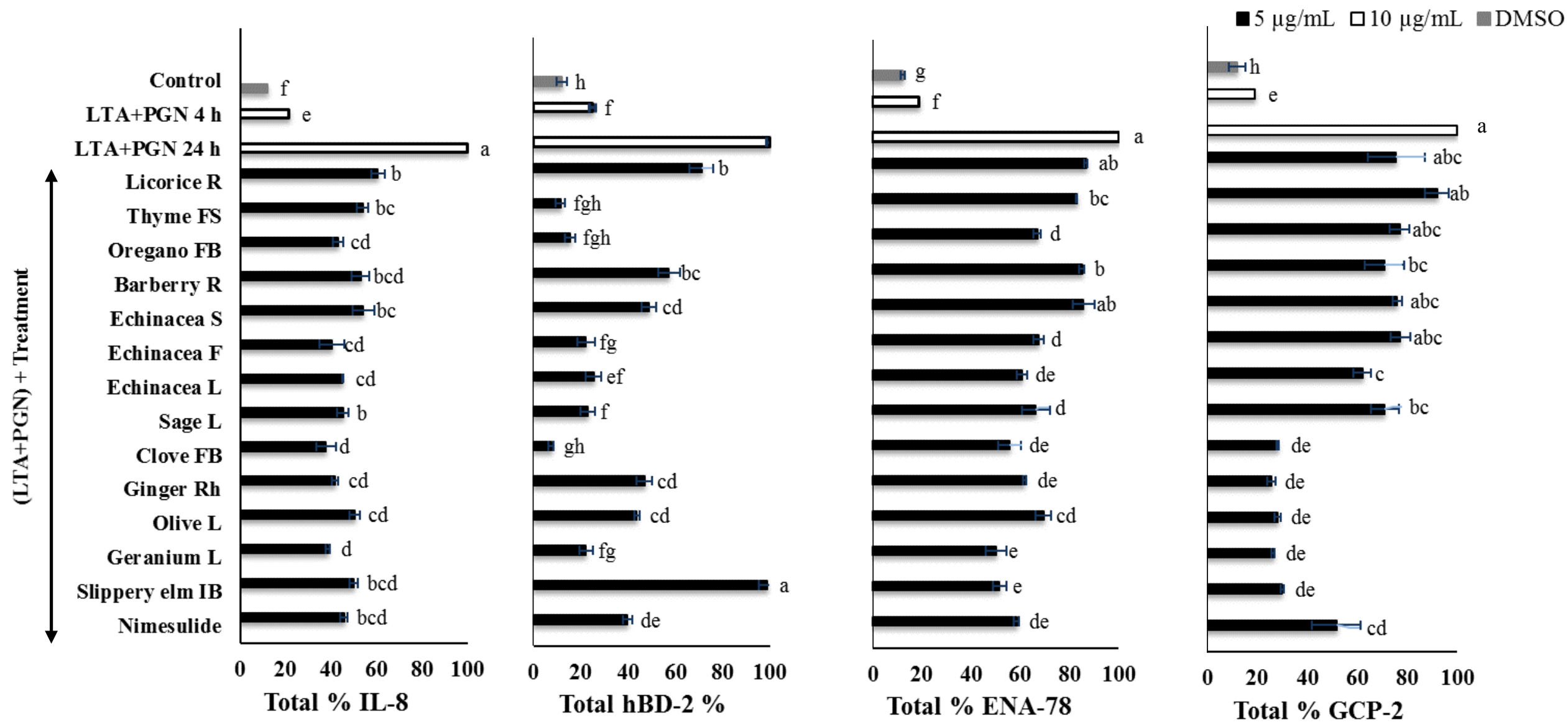